\title{
Early age reproduction in female savanna elephants (Loxodonta africana) after severe poaching
}

\author{
M. J. Owens* and D. Owens \\ Owens Foundation for Wildlife Conservation, PO Box 870530, Stone Mountain, GA, U.S.A.
}

\begin{abstract}
A 10-year study revealed that after severe poaching (>93\% killed) of elephants (Loxodonta africana) in Zambia's North Luangwa National Park (NLNP) during the 1970s and 1980s, the age of reproduction in females was greatly reduced. Fifty-eight per cent of births were delivered by females aged 8.5-14 years, an age at which elephants were reported to be sexually immature in nearby South Luangwa National Park (SLNP) before poaching. The mean age of females at first birth (AFB) (1993, 1994) was 11.3 years. Prior to poaching, the mean age AFB in SLNP was 16 years. The NLNP age structure and sex ratio were skewed, mean family unit size was reduced, and $37 \%$ of family units contained no females older than 15 years. Twenty-eight per cent of family units were comprised entirely of a single mother and her calf, and $8 \%$ of units consisted only of orphans who would have been considered sexually immature prior to poaching. Only $6 \%$ of survivors were older than 20 years, the age at which females in little-poached populations generally become most reproductively active. After a community-based conservation programme and the UN-CITES ban on the ivory trade were introduced, no elephants were recorded killed. In spite of a high reproductive rate, 6 years after poaching decreased, the density of the NLNP population had not increased, supporting predictions that the removal of older matriarchs from family units will have serious consequences on the recovery of this species.
\end{abstract}

Key words: community-based conservation, early age reproduction, elephants, ivory trade/ban, poaching, social dynamics

*Correspondence: E-mail: mdykes@owens-foundation.org

\section{Résumé}

Une étude qui a duré dix ans a révélé qu'après un braconnage très grave (>93\% tués) des éléphants (Loxodonta africana) dans le Parc National de Luangwa Nord (NLNP), en Zambie au cours des années 1970 et 1980, l'âge de la reproduction chez les femelles a fort baissé. Cinquante-huit pour cent des naissances se sont passées chez des femelles qui avaient entre 8,5 et 14 ans, un âge auquel les éléphants étaient dits être encore sexuellement immatures dans le Parc National de Luangwa Sud (SLNP), tout proche, avant le braconnage. L'âge moyen des femelles à la première mise-bas (AFB - at first birth) $(1993,1994)$ était de 11,3 ans. Avant le braconnage, l'âge moyen à la première mise-bas était de 16 ans au SLNP. Au NLNP, la structure d'âge et le sex-ratio ont été faussés, la taille moyenne de l'unité familiale a été réduite, et $37 \%$ des familles ne contiennent aucune femelle de plus de 15 ans. Vingt-huit pour cent des unités familiales n'étaient composées que d'une mère seule et de son jeune, et huit pour cent n'étaient composées que d'orphelins qui devaient être considérés comme sexuellement immatures avant le braconnage. Seuls six pour cent des survivants avaient plus de 20 ans, l'âge auquel les femelles de populations peu braconnées deviennent généralement les plus actives en matière de reproduction. Après l'introduction d'un programme de conservation communautaire et l'interdiction, par la CITES-UN, du commerce de l'ivoire, on n'a plus enregistré aucun massacre d'éléphant. Malgré un taux élevé de reproduction, la densité de population du NLNP n'a pas augmenté, ce qui conforte les prédictions que l'enlèvement des plus vieilles matriarches des unités familiales aura de sérieuses conséquences sur la restauration de cette espèce. 


\section{Introduction}

African savanna elephants experiencing comparatively little poaching pressure live in matriarchal societies of stable, cohesive family units of female relatives and their calves (Buss, 1961; Douglas-Hamilton, 1972; Moss \& Poole, 1983; Moss, 1988). Males disperse from natal units at an average of 14 years of age (Lee \& Moss, 1999). Females may conceive as young as 10 years of age (Laws, 1969), and the youngest age of first birth (AFB) in Amboseli was 8.9 years (Moss, 2001). However, females usually begin reproducing after the age of 14; mean AFB for Amboseli females was 14.1 years (Moss, 2001). Prior to heavy poaching, the youngest age at which nearby South Luangwa National Park (SLNP) females first ovulated was 11 years (mean 14), and the mean AFB was 16 years (Hanks, 1972). In little poached populations, males do not begin to reproduce until 25-30 years of age, reaching their reproductive prime between 40 and 50 (Poole, 1989). Prior to poaching, when the SLNP population density was considered high, individuals 1-5 years of age comprised $17.5 \%$ of the population (Hanks, 1979), and the sex ratio of SLNP elephants up to the age of 16 was equal (Hanks, 1972).

Matriarchs, which may live up to 65 years but are usually at least 35 years old (Moss, 2001), are reservoirs of social knowledge (Moss, 1988; McComb et al., 2001). Seventy-four per cent of family units in Amboseli were led by females aged more than 30 years (Poole, 1989). The presence of older matriarchs increases per capita reproductive success in family units (McComb et al., 2001), and allo-mothering by female relatives in family units enhances calf survival (Lee, 1987).

From the 1970s through the 1980s, ivory poachers reduced Africa's savanna elephants from $c .1 .3$ million to 500,000 (Douglas-Hamilton, 1987). Poaching alters elephant population age structure (Poole, 1989; Barnes \& Kapela, 1991), sex ratio (Lewis, 1984; Poole, 1989), aspects of social behaviour (Poole, 1989; Nyakaana et al., 2001), the percentage of individuals without tusks (Poole, 1989; Jachmann, Berry \& Imae, 1995) and reproductive patterns (Poole \& Thomsen, 1989). Highly skewed sex ratios in favour of females and the loss of adult females from family units have negatively impacted elephant reproductive rates, and these factors will impose limitations on a population's ability to recover (Poole, 1989). Reproductive rates are predicted to be lower in poached populations that do not aggregate because scarce males will have more difficulty locating receptive females (Poole, 1989; Poole \& Moss, 1989). Poole (1989) predicted that the social disruption of family units and reproductive behavioural patterns caused by poaching will most likely lead to lowered conception rates, older AFB and a lower reproductive rate.

Here we describe some of the marked changes to elephant social dynamics and reproductive biology after poachers reduced the population of North Luangwa National Park (NLNP), Zambia by 93\%, and suggest reasons why certain parameters did not conform to some of the above predictions.

\section{Materials and methods}

This study was conducted from 1986 through 1996 in NLNP, Zambia.

\section{Population estimates and trends}

We estimated trends in the population density of elephants in NLNP by flying biannual aerial surveys from 1986 through 1996 using the same sampling intensity and formula for computation as used in two previous censuses flown in 1973 (Naylor et al., 1973) and 1985 (Lewis, 1985). We confirmed aerial census estimates by flying annual whole counts of the population when most of the elephants formed aggregations on the open Luangwa River floodplain in the early rainy season of those years.

\section{Aging elephants}

Annually, between 1990 and 1996, we aged c. 60\% of the female elephants and their young, and as many males as possible by walking transects along all the major rivers of the park during the dry season when elephants concentrated in those areas. In addition, groups were located and identified in remote areas and thick bush by helicopter. The helicopter could be landed for aging elephants. The composition of all groups was described (see below), and all individuals within the groups were aged. To age elephants, we measured the length of the hind footprint as described in Western, Moss \& Georgiadis (1983) and Lee \& Moss (1995), which is an appropriate technique for Luangwa elephants because they are of similar size (Western et al., 1983; Lee \& Moss, 1995). Before 1994, the stress from heavy poaching made many elephants too difficult to 
approach for aging by direct observations. By 1994, family units and males could be observed and described from a distance before measuring prints or estimating shoulder heights. Thus this paper reports the age estimates of 695 elephants (females and their young) and 69 males made in 1994. These data provide birthing ages (BA) and ages AFB for birthing events as far back as the ages of the oldest calves.

\section{Reproductive dynamics}

Birthing ages were derived by subtracting the estimated age of an infant or calf from the estimated age of its mother in 248 females and their young (695 total) in 146 cow/calf groups in 1994. The mother's age at ovulation was calculated by subtracting a 22-month gestation period from observed or estimated birth dates. A Kaplan-Meier survival analysis was used to calculate AFB for females with infants born in 1993 and 1994.

To monitor births, group sizes and compositions, a female in each of 16 family units was immobilized, affixed with a radio transmitter collar, and observed from the ground and twice weekly from a fixed-wing aircraft and/or helicopter. Births to two known-age females were recorded (E. van der Westhuizen, pers. comm.) after the end of our study period.

\section{Family unit composition}

The composition of each family unit was described according to the definitions similar to Poole, 1989: (i) breeding group with no adult females present; (ii) breeding group with at least one subadult mother; (iii) single adult mother; (iv) single subadult mother; (v) breeding group entirely composed of orphans; (vi) normal except for at least one orphan; (vii) normal (no orphans, no subadult mothers, adult female $>15$ present); (viii) apparently intact with an old ( $>30$ years) matriarch.

Many NLNP family units had more calves present than the number of females older than 14 years, which could have been their mothers. It was hypothesized that females 14 years and younger were giving birth. This was confirmed by direct observation of infants suckling females 14 years and younger, which could only have been the offspring of the female because elephants do not nurse calves other than their own (Moss, 1988); and by direct observation of two known-aged females younger than 14 years giving birth a total of four times.
Calves <2 years of age cannot survive without their mothers (Poole, 1989); thus any calves of this age in the family units were not orphans, but were instead the offspring of the young mothers present in the family units.

As most groups of cows and calves in NLNP did not fit the definition of a family unit as given above, the term cow/calf group is used when appropriate as in Poole (1989). Unfortunately, the mean size of family units cannot be compared with that of the neighbouring SLNP population before poaching because that mean was derived from culled elephants and larger family units were avoided when culling (Hanks, 1979).

\section{Sex ratio}

The sex ratio was calculated from direct observations of elephants counted and aged during the river walks of 1994.

\section{Results}

\section{Trends in population density}

The NLNP elephant population density declined by an estimated 93\%, from 17,500 in 1973 (Naylor et al., 1973) to 1300 in 1996 (Fig. 1) because of illegal shooting for ivory.

\section{Mean family unit size}

The mean cow/calf group size of NLNP elephants after poaching was 4.7 individuals ( $\mathrm{n}=146$; range $1-15)$. Family units of one individual were counted because these consisted of one female or one young orphan which belonged to a larger family unit before it was shot by poachers. By comparison in 1991, the mean family unit size of the relatively little poached population in Amboseli National Park, Kenya, was 17.4 ( $\mathrm{n}=52$; range 3-48) (Moss, 2001). In 1985, the mean group size in Mikumi was 8.1 elephants (range 2-45) after poaching (Ihde, 1987); and after poaching in Queen Elizabeth National Park the mean group size increased from 7.2 (1971) to 10.8 in 1976 (Eltringham \& Malpas, 1980).

Twenty-eight per cent of NLNP cow/calf groups were comprised of only a single female with her one offspring ( $\mathrm{n}=25$ single mothers $<15$ years; $\mathrm{n}=16$ single mothers $>15$ years) (Table 1). In the 1970s, before poaching in 
Fig 1 The population density of elephants in North Luangwa National Park, Zambia, decreased because of ivory poaching. The 1973 (Naylor et al., 1973) and 1985 (Lewis, 1985) data are from aerial surveys conducted before this study. Heavy poaching decreased in 1991. Primary observations ended in 1996

Table 1 Family unit $(\mathrm{n}=146)$ composition

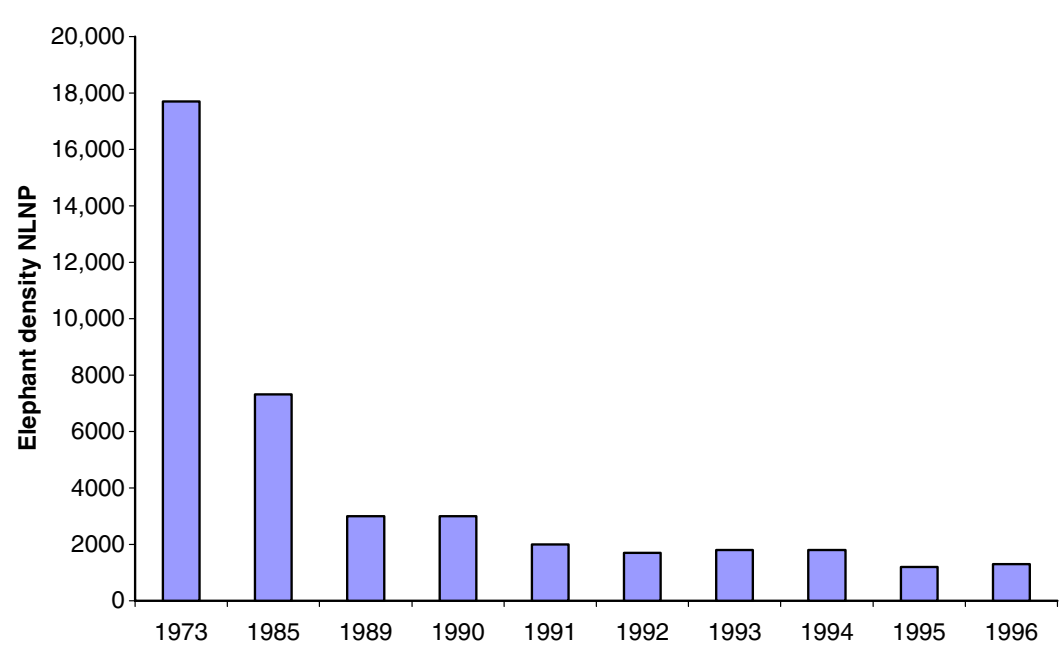

\begin{tabular}{llr}
\hline Category & & $\mathrm{n}(\%)$ \\
\hline 1 & Breeding groups with no adults & $29(20)$ \\
2 & Breeding groups with at least one subadult mother & $44(30)$ \\
3 & One adult mother & $16(11)$ \\
4 & One subadult mother & $25(17)$ \\
5 & Group of nonbreeding orphans & $11(8)$ \\
6 & Normal except for at least one orphan & $6(4)$ \\
7 & Normal (no subadult mothers, no orphans, adult female) & $15(10)$ \\
8 & Family units with matriarch >30 years & $12(8)$ \\
\hline
\end{tabular}

nearby SLNP, only 3\% $(\mathrm{n}=4)$ of family units were as small as two individuals (Hanks, 1979).

\section{Aggregations}

Although it has been reported that elephants in the Luangwa Valley do not aggregate (Douglas-Hamilton et al, 1979), we observed NLNP elephants, including radio collared family units, congregating in aggregations of 21 to $500+$ individuals (39\% of the total population) seventeen times in 1994 through 1996 to forage on quickly growing floodplain grasses during the early rainy season. When the grasses grew taller, the aggregation dispersed and family units returned to their normal home ranges within the national park. As they congregated during the time of year when poaching incidents were least frequent, we have assumed that they formed temporary aggregations to take advantage of this concentrated resource, and/or to re-establish contact with bond groups, rather than forming permanent aggregations in response to poaching pressure as reported by Eltringham \& Malpas (1980) in other areas.
Early age reproduction

Direct observations and foot print data from a total of 695 elephants (females and their young) revealed that many exceptionally young females gave birth at an age when they would have been considered sexually immature in nonpoached populations (Hanks, 1972; Moss, 2001).

A Kaplan-Meier survival analysis of AFB suggests that the probability of giving birth for the first time was over $50 \%$ for females aged between 11 and 12 years (1993 and 1994 combined) (Fig. 2), as compared with 14 and 15 years in Amboseli (Moss, 2001). The mean age that females $(\mathrm{n}=79)$ produced their first calf was 11.3 years ( $\mathrm{s}=2.0$ ); the median AFB was 11.0 years. Prior to poaching, the mean AFB in SLNP was 16 years (Hanks, 1972). In areas of little poaching, females between the ages of 8-9 years had $0.4 \%$ probability of giving birth, and those between 9-10 years 1.3\% probability (Moss, 2001). NLNP females of $8-9$ years had a $1.2 \%$ probability of giving birth. 


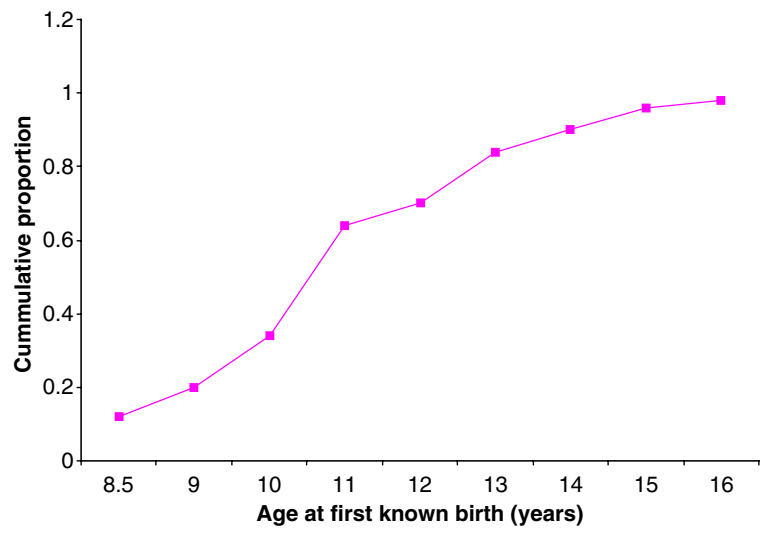

Fig 2 Probability of first birth occurring at each age for NLNP females (1993 and 1994). Mean age of first birth was 11.3 years; median age of first birth was 11.0 years $(\mathrm{s}=2.0 ; \mathrm{n}=79)$

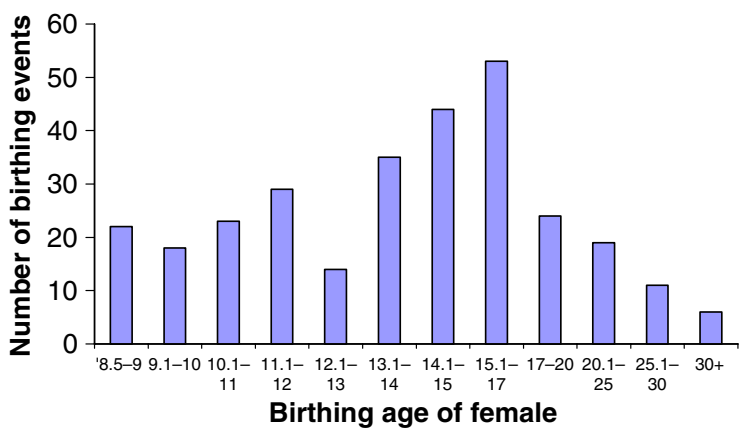

Fig 3 The birthing age of 248 females (ages 8.5 to $30+$ years) in 321 birthing events from 1988 to 1994 . Mean $=14.8$ years; median $=13.4$ years. (These include all birthing events, not only age at first birth)

Fifty-eight per cent $(\mathrm{n}=186)$ of 321 births between 1988 and 1994 were by females $(\mathrm{n}=248) 14$ years or younger (Fig. 3). The mean BA of females ( $\mathrm{n}=321$ births; 248 females) was 14.78 years (8.5-31 years); median $=13.42$.

Seven females each produced two calves before the age of 15 . By the age of 16 years, one female orphan had given birth to three calves (two births observed after study period, pers comm.), and had one grand-calf (mother's known age 8.5-years old; birth observed after study period, E. Van der Westhuizen, pers. comm.).

\section{Males}

After leaving their natal groups, NLNP males wandered on their own or formed temporary groups with other males.

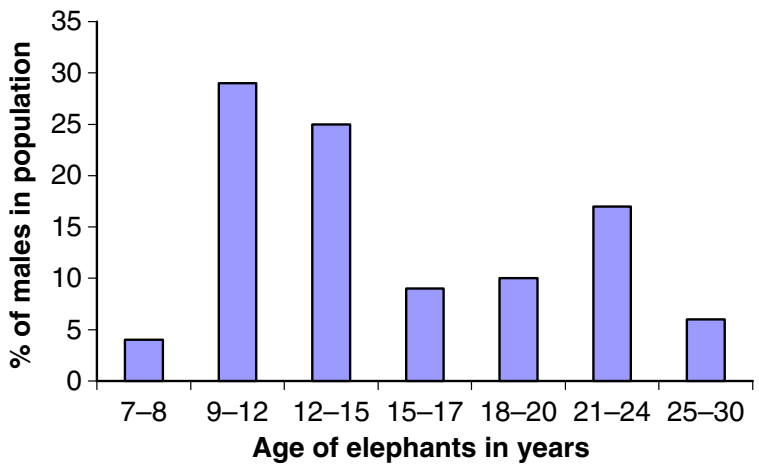

Fig 4 The 1994 age structure of 69 males which had left their natal family units

During the 1994 river-walk transects and helicopter surveys, 69 males, which were no longer associated with their natal group, were encountered. Males left natal groups as young as 7 - to 8 -years old $(\mathrm{n}=3)$. Forty-two per cent $(\mathrm{n}=29)$ of them were $>15-30$ years of age (Fig. 4). In 10 years of ground and aerial observations, we only saw one male as old as 40 years.

\section{Sex ratio}

The sex ratio of adult ( $>15$ years) females to adult $(>15$ years) males in 1994 was $81 \%$ females $(n=128)$ to $19 \%$ males $(\mathrm{n}=29)$.

\section{Reproductive rate}

Thirty-five per cent of the NLNP population was younger than 5 years of age (Fig. 5), a high reproductive rate for elephants according to Poole (1989). During the 1970s, prior to heavy poaching when the SLNP elephant population was considered too dense for its habitat (Hanks, 1979), the frequency of individuals younger than 5 years of age was $17.5 \%$. Thus, the reproductive rate of NLNP elephants after poachers had killed $93 \%$ of the population was higher than that of the SLNP population before poaching.

\section{Orphans/family units without adult females}

The presence of adult female relatives (>15 years) in family units enhances calf survival (Lee, 1987). However, in the NLNP population, there were no surviving adult females (mothers or relatives) more than 15-years old in 
Fig 5 The age structure of 695 elephant females and young in North Luangwa National Park, Zambia, in 1994

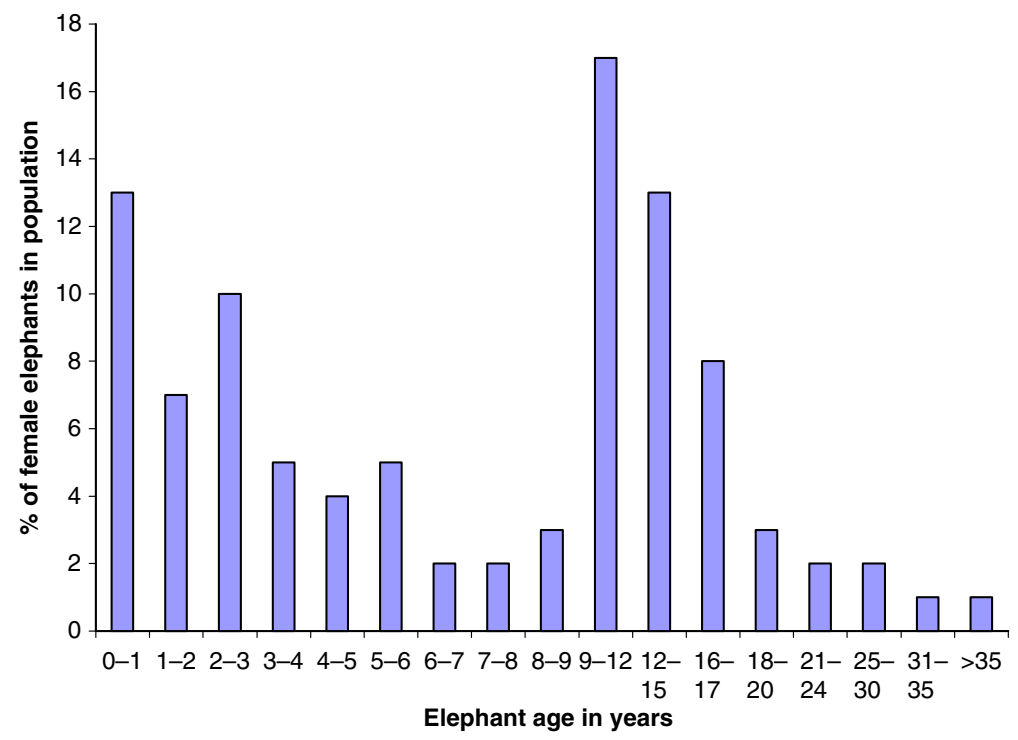

were older than 20 years, compared with a range of 2335\% for the little poached Amboseli elephants from 1976 to 1996 (Moss, 2001), and 50.6\% in neighbouring SLNP before poaching (Hanks, 1979).

Based on the previously reported earliest age at which females of the Luangwa Valley reproduced prior to poaching (16 years, Hanks, 1972), only $17 \%$ of the NLNP females would have been sexually mature (Fig. 5). However, because they were ovulating and giving birth at much younger ages than previously reported, 50\% (Fig. 5) were of breeding age (8.5->20 years), which is consistent with the range in SLNP before poaching (Hanks, 1972).

\section{Population density after poaching}

A community-based conservation program (North Luangwa Conservation Project) offering small business development, jobs, health care and education to people in fourteen villages near the national park was introduced in 1986. In the subsequent 4 years poaching decreased by more than 56\% (Fig. 6). After the 1991 devaluation of black market ivory by the UN-CITES ban on the ivory trade, and after community assistance alternatives were accepted by many would-be poachers, the poaching of elephants declined to none recorded in 1996.

Even with females breeding at much younger ages, 6 years after observed poaching virtually ceased (Fig. 6) the population density of NLNP had not increased (Fig. 1). 


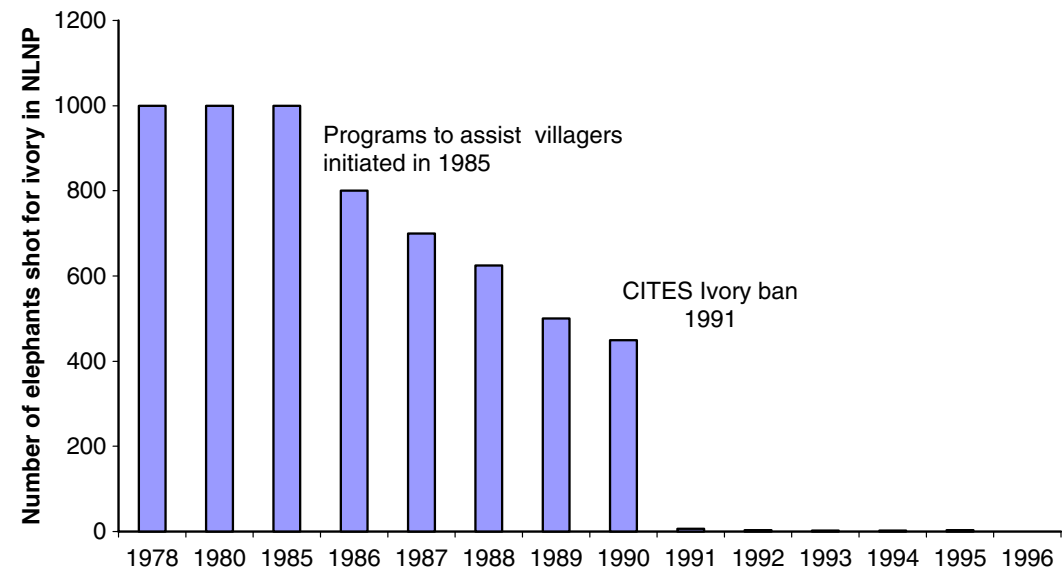

Fig 6 The number of elephants shot for ivory in North Luangwa National Park, Zambia. Data from 1986 to 1996 are from direct observation, aerial surveys and ivory confiscated by Zambian National Parks and Wildlife Services. Data prior to 1986 are from aerial surveys, ivory confiscated and records kept by Zambian National Parks and Wildlife Services

\section{Tusklessness}

Our ground observations and helicopter aerial surveys revealed that $38 \%$ of male and female adult elephants were tuskless, the same percentage reported for South Luangwa after heavy poaching (Jachmann et al., 1995).

\section{Discussion}

It has been predicted that in heavily poached populations of elephants, the social disruption of family units and the low frequency of adults will lead to lowered conception rates, older ages at first reproduction, and a lower reproductive rate (Poole, 1989). However in the heavily poached NLNP population, in which the number of adults and the mean cow/calf group size was reduced, and in which many adult females were removed from family units, females first ovulated and reproduced at much earlier ages, and the reproduction rate was higher than before poaching.

It was also predicted that in poached populations with scarce adult males, with adult females less numerous in family units, and aggregations not occurring, reproductive rates would be low (Poole, 1989). The reproductive rate will be less depressed in heavily poached populations in which aggregations do occur because the few surviving males would locate receptive females relatively more frequently because of their proximity during the aggregation. Our observations support this contention: NLNP males were scarce, many groups lacked adult females, aggregations did occur, and the reproductive rate was higher (34\%) than prior to poaching (17.5\% SLNP).
However, in spite of a higher reproductive rate and an early age at first reproduction among females, the NLNP population did not increase for 6 years after poaching was reduced. This observation supports the predictions that the removal of females from family units will negatively impact recovery rates (Poole, 1989). The presence of older matriarchs increases per capita reproductive success in the family units (McComb et al., 2001), and allo-mothering by female relatives in family units enhances calf survival (Lee, 1987). Amboseli calves of the youngest females were more likely to die (Moss, 2001). In populations experiencing low levels of poaching, the most reproductively active females were between 20 and 45 years of age (Moss, 1988). However, in the NLNP population, only $6 \%$ were in this age class, and there were no surviving adults ( $>15$ years of age) in $37 \%$ of family units with calves. Nearly $70 \%$ of cow/calf groups had at least one female 14 years or younger with a calf. That the population density did not increase may thus be because of high infant mortality as a function of poor maternal care by inexperienced mothers, reduced allo-mothering from relatives, most of which had been shot, and the loss of survival knowledge that would have existed among older individuals had they survived.

In little poached populations, male elephants do not begin reproducing until 25-30 years of age, reaching their reproductive prime at 40 years (Poole, 1989). In NLNP only $6 \%$ of males were 25-30 years old. We observed males younger than 15 years of age chasing females, and although we did not observe copulations by these males, we predict that males in NLNP are breeding at younger ages than in little poached populations. 
The NLNP age structure is similar to that of the heavily poached ( $>60 \%$ poached) population of Ruaha National Park, Tanzania (Barnes \& Kapela, 1991). In NLNP, individuals between the ages of 9 and 20 years are probably the most numerous because during the years of heavy poaching, they were old enough to survive as orphans, but too young to have tusks large enough to be sought by poachers. Individuals between 3 and 9 years were most likely under-represented because they were too young to survive as orphans when poachers shot their mothers. Older age class individuals survived in fewer numbers because they were shot for their ivory.

Age at sexual maturity varies in different elephant populations (Eltringham, 1982), because of complex factors including an individual's growth rate, nutrition, and the prevailing ecological and social conditions (Moss, 2001). The mean age of puberty increases with an increase in population density in elephants (Hanks \& McIntosh, 1973). The exceptional early-age reproduction observed in NLNP females is most likely a function of low population density and the removal of older females. In other mammalian populations, particularly ungulates experiencing high rates of mortality and low densities, individuals become sexually mature at younger ages and frequently exhibit increased fecundity (Clutton-Brock, Albon \& Guinness, 1982). The frequency and onset of early-age reproduction in NLNP are the highest and youngest yet reported, occurring in one of the most heavily poached populations in Africa.

In some mammals, older dominant females suppress reproduction in younger subordinates (MacDonald, 1979; Owens \& Owens, 1984). That very young NLNP females ovulated and gave birth after poachers had removed older females may suggest that such suppression was occurring in this elephant population before poaching. This is not an alternative hypothesis for density-dependent early age reproduction, but may be a proximate cause for females ovulating at younger ages and at a higher frequency than previously observed.

That NLNP elephants exhibited a younger female age at first reproduction, a higher reproductive rate, but not an increase in population density 6 years after poaching are important for modellers and others attempting to project the recovery of Africa's heavily poached elephant populations. These observations also have broader implications for the debate on how long-lived mammalian species respond to profound mortality.

\section{Acknowledgements}

We thank the Owens Foundation for Wildlife Conservation, the Frankfurt Zoological Society and the late H.R.H. Prince Bernhard of the Netherlands for funding the research. We are grateful to the Zambian National Parks and Wildlife Services for permission to conduct the study; M. \& B. Dykes, and H. Cooper for technical and logistical support; B. Zulu, M. Katonga, M. \& T. Boulton, A. Haynes, R. and A. Haylock, P. Smith, and D. Shah-Smith, I. Spencer, and E. North for assistance in the field; J Cooper for computer programming, and Joel Berger, Rob Pierce, and Dawn Mehra for reviewing the manuscript.

\section{References}

ABE, E.L. (1994) The behavioural ecology of elephant survivors in Queen Elizabeth National Park, Uganda, PhD thesis, Univeristy of Cambridge, Cambridge, UK.

BARNES, R.F.W. \& KAPELA, E.B. (1991) Changes in the Ruaha elephant population caused by poaching. Afr. J. Ecol. 29, 289-294.

Buss, I.O. (1961) Some observations of the food habits of the African elephant. J. Wildl. Manage. 25, 131-148.

Clutton-Brock, H., Albon, S. \& Guinness, F.E. (1982) Red Deer Ecology and Behavior of Two Sexes. University of Chicago Press, Chicago.

Douglas-Hamilton, I.. (1972) On the ecology and behaviour of the African elephant. $\mathrm{PhD}$ thesis, University of Oxford, Oxford, UK.

Douglas-Hamilton, I., Hillman, A.K.K., Holt, P. \& Ansell, P. (1979) Luangwa Valley. IUCN/NYZS/WWF Elephant, rhino and wildlife survey. Typescript.

Douglas-Hamilton, I. (1987) African elephants: population trends and their causes. Oryx. 21, 11-24.

Eltringham, S.K. (1982) Elephants. Blandford Press, Dorset.

Eltringham, S.K. \& MaLPAS, R.C. (1980) The decline in elephant numbers in Rwenzori and Kabalega National Parks, Uganda. Afr. J. Ecol. 18, 73-86.

HANKs, J. (1972) Reproduction of elephant, Loxodonta africana, in the Luangwa Valley, Zambia. J. Reprod. Fertil. 30, 13-26.

Hanks, J. (1979) A Struggle for Survival: The Elephant Problem. C. Struik Publishers, Cape Town.

Hanks, J. \& Mcintosh, J.E.A. (1973) Population dynamics of the African elephant. J. Zool. (Lond.) 169, 29-38.

IHDE, S. (1987) The current elephant status in Milumi National Park.Typescript. 11 pp.

Jachmann, H., BerRy, P.S.M. \& IMAE, H. (1995) Tusklessness in African Elephants: a future trend. Afr. J. Ecol. 33, 230-235.

Laws, R.M. (1969) Aspects of reproduction in the African elephant, Loxodonta africana. J. Reprod. Fertil. Suppl., 6, 193217.

LEE, P.C. (1987) Allomothering among African elephants. Anim. Behav.. 35, 278-291. 
Lee, P.C. \& Moss, C.J. (1999) The social context for learning and behvavioural development among wild African elephants. In: Mammalian Social Learning (Eds H. O. Box and K. R. GiBson). Cambridge University Press, Cambridge.

LeE, P.C. \& Moss, C.J. (1995) Statural growth in known-age elephants (Loxodonta Africana). J. Zool. (Lond.) 236, 29-41.

LewIS, D. (1984) Demographic changes in the Luangwa Valley elephants. Biol. Conserv. 29, 7-14.

LEwIs, D. (1985) Population Density of Luangwa Elephants. Report to Zambian National Parks and Wildlife Services, Lusaka.

Macdonald, W. (1979) The ecology of carnivore social behavior. Nature 282, 69-71.

McComb, K., Moss, C., Durant, S.M., Baker, L. \& Sayialel, S. (2001) Matriarchs as repositories of social knowledge in African elephants. Science 292, 491-494.

Moss, C.J. (1988) Elephant Memories. William Morrow, New York, NY.

Moss, C.J. (2001) The demography of an African elephant (Loxodonata africana) population in Amboseli, Kenya. J. Zool. (Lond.) 255, 145-156.

Moss, C.J. \& Poole, J.H. (1983) Relationships and social structure of African Elephants. In: Primate Social Relationships (Ed. R. A. HINDE). Blackwell, Oxford.

Naylor, J.N., Caughley, G.J., Abel, N.D.J. \& Liberg, O. (1973) The Ecology of the Luangwa Valley, Zambia. FAO Report, Rome, 144528, 267-275.
Nyakaana, S., Abe, E.L., Arctander, P. \& Siegismund, H.R. (2001) DNA evidence for elephant social behaviour breakdown in Queen Elizabeth Park, Uganda. Anim. Conserv. 4, 231-237.

OwENS, D.D. \& OwENS, M.J. (1984) Helping behaviour in brown hyenas. Nature 308, 843-845.

PooLE, J.H.. (1989) The effects of poaching on the age structure and social and reproductive patterns of selected East African elephant populations. The Ivory Trade and the Future of the African Elephant, Vol. II, Technical papers prepared by the Ivory Trade Review Group for the 7th CITES COP.

Poole, J.H. \& Moss, C.J. (1989) Elephant mate searching, group dynamics and vocal and olfactory communication. Symp. Zool. Soc. Lond. 61, 111-125.

Poole, J.H. \& Thomsen, J.B. (1989) Elephants are not beetles: implications of the ivory trade for the survival of the African elephant. Oryx, 23, 188-198.

Western, D., Moss, C.J. \& Georgiadis, N. (1983) Age estimation and population age structure of elephants from foot print dimensions. J. Wildl. Manage. 47, 1192-1197.

(Manuscript accepted 13 June 2008)

doi: 10.1111/j.1365-2028.2008.01001.x 